\title{
SOSIALISASI INFORMASI DAN KOMUNIKASI JAMINAN KESEHATAN BPJS DALAM MENINGKATKAN PELAYANAN KESEHATAN LANSIA
}

\section{The Social Security Administrator Health Insurance Information and Communication Dissemination Activities in Improving the Health Services of the Elderly}

\author{
Riskha Dora Candra Dewi \\ Prodi Rekam Medik, Politeknik Negeri Jember \\ Email: riskhadora@polije.ac.id
}

\begin{abstract}
ABSTRAK
Pendahuluan: Permasalahan lansia tentang BPJS kesehatan yaitu lansia masih belum memahami mengenai cara mendapatkan dan tahapan dalam pengobatan dengan menggunakan BPJS mulai dari rujukan pelayanan kesehatan tingkat pertama ke rujukan pelayanan kesehatan tingkat paling tinggi. Lansia juga belum mendapatkan informasi secara maksimal mengenai jaminan kesehatan BPJS. Metodologi: Metode pemecahan permasalahan dalam pengabdian masyarakat menggunakan edukasi oleh tenaga kesehatan pada lansia. Konsep metode edukasi meliputi: 1) tahap orientasi; 2) kerja; 3) resolusi. Memberikan materi meliputi: 1) pengertian BPJS; 2) jenis-jenis BPJS; 3) pelayanan-pelayanan dalam BPJS; 4) pembayaran iuran BPJS; 5) prosedur pendaftaran BPJS; 6) manfaat BPJS bagi lansia. Hasil: Hasil pengabdian masyarakat memberikan materi-tentang BPJS selama 30 menit. Kesimpulan: Kegiatan sosialisasi informasi dan komunikasi jaminan kesehatan BPJS dalam meningkatkan pelayanan kesehatan lansia dapat meningkatkan pola hidup sehat lansia, sehingga lansia tetap produktif dan mendapatkan pelayanan kesehatan yang terpenuhi secara komprehensif dan bertanggung jawab
\end{abstract}

Kata Kunci : BPJS kesehatan, informasi, komunikasi, lansia, pelayanan kesehatan

\begin{abstract}
Introduction: The problem of the elderly about Social Security Administrator (SSA) of health is that the elderly still do not understand how to obtain and stages in treatment using SSA starting from the referral of first level health services to the highest level referral health services. The elderly also did not get maximum information about SSA of health insurance. Method: The method of solving problems in community service uses education by health workers in the elderly. Provide material covering: 1) understanding of SSA; 2) types; 3) services; 4) payment of SSA contributions; 5) SSA registration procedure; 6) the benefits of SSA for the elderly. The concept of the educational method includes: 1) the orientation phase; 2) work; 3) resolution. Result: The results of community service provide material about SSA for 30 minutes. Conclusion: The SSA health insurance information and communication dissemination activities in improving the health services of the elderly can improve the healthy lifestyle of the elderly, so that the elderly remain productive and obtain comprehensive and responsible health services
\end{abstract}

Keywords : information, communication, elderly, health services, social security administrator of health

\section{PENDAHULUAN}

Peningkatan kualitas pelayanan publik pada Badan Penyelenggara Jaminan Sosial (BPJS) Kesehatan sangatlah penting agar dapat meningkatkan kepuasan terhadap masyarakat dalam memperoleh pelayanan kesehatan yang aman, bermutu, sistem serta harga yang terjangkau. Pelayanan bidang kesehatan belum memenuhi standar pelayanan publik yang baik, akses masyarakat untuk mendapatkan manfaat pelayanan sangat terbatas, masyarakat belum bisa mendapatkan pelayanan di semua fasilitas kesehatan (Widiastuti, 2018).

Permasalahan komunikasi dan informasi yang kurang baik (Rosidah \& Apriyani, 2018). Hasil studi di lapangan bahwa permasalahan lansia tentang BPJS kesehatan yaitu lansia masih belum memahami mengenai cara mendapatkan dan tahapan dalam pengobatan dengan menggunakan BPJS mulai dari rujukan pelayanan kesehatan tingkat pertama ke rujukan pelayanan kesehatan tingkat paling tinggi. Lansia juga belum mendapatkan 
informasi secara maksimal mengenai jaminan kesehatan BPJS.

Di Negara Indonesia populasi lanjut usia meningkat per tahun. Tahun 1980 sebanyak 5.45\%; tahun 2006 meningkat 8.90\%; tahun 2010 berubah 9.77\%; tahun 2014 berubah $10.60 \%$ dan tahun 2020 sekitar $11.34 \%$ dari jumlah keseluruhan populasi (Vinsur \& Sutiyarsih, 2019). Populasi lansia secara global diperkirakan terus meningkat pada tahun 2013 terdapat 13,4 juta jiwa berusia di atas 60 tahun, dan diperkirakan pada tahun 2050 jumlah lansia di dunia sekitar 25,3 juta jiwa. Peningkatan jumlah lansia di Indonesia cukup signifikan di tahun 2013 terdapat 8,9 juta jiwa berusia di atas 60 tahun, dan diprediksi pada tahun 2050 jumlah lansia di Indonesia akan mencapai 21,4 juta jiwa dan di Jawa Timur pada tahun 2015 terdapat 11,5 juta jiwa dikategorikan lansia (Infodatin Kemenkes RI, 2016).

Pemerintah Inggris melalui National Health Service (NHS) memberikan subsidi kesehatan kepada masyarakatnya hingga $90 \%$. Dengan sistem seperti itu masyarakat dapat menikmati pelayanan kesehatan yang sangat murah (Widiastuti, 2018).

Factor penyebab rendahnya pengetahuan atau informasi yaitu tingkat pendidikan masyarakat yang merupakan faktor potensial penyebab rendahnya kepesertaan BPJS di sektor informal (Rosidah \& Apriyani, 2018). Factor lain penyebab rendahnya informasi dan komunikasi lansia tentang jaminan kesehatan BPJS antara lain factor kurangnya akses untuk mendapatkan informasi yang akurat tentang jaminan BPJS, factor kemauan dari diri lansia untuk mendapatkan informasi, dan faktor tingkat pendidikan. Kondisi tersebut berdampak pada status kesehatan lansia. Lansia tidak optimal dalam memeriksakan diri ke pelayanan kesehatan dengan menggunakan BPJS, sehingga kualitas kesehatan belum optimal.

Salah satu upaya untuk menangani permasalahan kesehatan lansia di atas adalah dengan melakukan edukasi atau penyuluhan kesehatan tentang sosialisasi jaminan kesehatan BPJS untuk lansia.

\section{METODE}

Tahapan pelaksanaan kegiatan pada pengabdian masyarakat ini yaitu menggunakan metode penyuluhan atau edukasi oleh tenaga kesehatan pada lansia. Tenaga kesehatan dalam kegiatan ini ada dua orang yang merupakan mitra kerja Politeknik Negeri Jember dan Universitas Jember. Konsep metode penyuluhan atau edukasi meliputi: 1) tahap orientasi; 2) kerja; dan 3) resolusi pada Gambar 1.

Strategi metode edukasi tahap orientasi meliputi: 1) salam terapeutik berisi tentang perkenalan nama dan bina hubungan saling percaya; 2) evaluasi pertemuan berisi tentang persiapan peserta yang akan diberikan edukasi yaitu lansia, dan menanyakan kondisi kesehatan peserta; 3) kontrak (topik, waktu, dan tempat). Kontrak topik berisi tentang tema pokok bahasan yang akan disampaikan dalam edukasi, kontrak waktu berisi tentang jadwal edukasi yang akan dilaksanakan, kontrak tempat berisi lokasi edukasi. Tahapan ini bertujuan untuk membina hubungan saling percaya antara tenaga kesehatan yang memberikan edukasi dengan lansia dan meningkatkan rasa percaya diri lansia terhadap kemampuannya dalam menerima dan kooperatif terhadap informasi dan komunikasi yang disampaikan oleh tenaga kesehatan.

Tahap kerja atau tahap implementasi merupakan tahap inti mengenai edukasi yang akan disampaikan meliputi: pengertian BPJS, jenis-jenis BPJS, pelayanan-pelayanan dalam BPJS, pembayaran iuran BPJS, prosedur pendaftaran BPJS, manfaat BPJS bagi lansia. Tahap ini bertujuan untuk memberikan informasi secara lengkap dan jelas terhadap lansia sehingga dapat meningkatkan pemahaman lansia.

Tahap resolusi meliputi: 1) evaluasi berisi tentang evaluasi respons peserta edukasi secara subyektif dan obyektif; 2) tindak lanjut berisi tentang penugasan atau latihan mandiri untuk peserta edukasi tentang tema yang telah diberikan oleh tenaga kesehatan; 3) kontrak yang akan datang berisi tentang topic atau tema baru yang akan disampaikan, waktu atau jadual edukasi, dan tempat edukasi. Tahap ini bertujuan sebagai evaluasi yang dilakukan pada lansia yang berupa evaluasi proses dan hasil 
terhadap edukasi yang telah dilakukan untuk mengetahui keberhasilan kegiatan.

Sarana prasarana dalam kegiatan ini menggunakan leaflet sebagai media untuk menyampaikan edukasi pada peserta pada Gambar 2.

Partisipasi peserta dalam program pengabdian masyarakat yaitu kooperatif dalam mengikuti edukasi mulai dari awal sampai dengan akhir sesi melalui partisipasi aktif bertanya dan mendengarkan secara aktif tentang tema yang disampaikan oleh petugas kesehatan.

Evaluasi keberhasilan sosialisasi informasi dan komunikasi jaminan kesehatan BPJS dalam meningkatkan pelayanan kesehatan lansia menggunakan deep interview atau wawancara mendalam menggunakan pertanyaan yang bersifat terbuka terhadap peserta lansia mengenai tema yang didapat dari kegiatan edukasi. Pertanyaan-pertanyaan tersebut meliputi: 1) apakah penggunaan media leaflet dan edukasi sebagai komponen sosialisasi informasi dan komunikasi mempermudah pemahaman peserta lansia?; 2) apakah informasi dan komunikasi mengenai fasilitas yang ditanggung oleh BPJS sangat membantu peserta lansia menuju pusat layanan kesehatan?; 3) apakah penggunaan bahasa lokal untuk menjelaskan semua informasi dan komunikasi mengenai jaminan kesehatan BPJS dalam meningkatkan pelayanan kesehatan lansia terhadap peserta lansia bermanfaat?

\section{HASIL DAN PEMBAHASAN HASIL}

\section{Tahap 1: Orientasi}

Tahapan ini merupakan tahapan pertama sebelum peserta lansia mendapatkan edukasi tentang sosialisasi informasi dan komunikasi jaminan kesehatan BPJS dalam meningkatkan pelayanan kesehatan lansia. Tahap pertama (orientasi) ini meliputi: 1) salam terapeutik; 2) evaluasi pertemuan; 3) kontrak (topik, waktu, dan tempat).

\section{Salam Terapeutik}

Salam terapeutik berisi tentang perkenalan nama dan bina hubungan saling percaya. Salam terapeutik ini merupakan langkah pertama untuk saling mengenal antara petugas kesehatan dengan peserta lansia. Perkenalan nama diharapkan tercipta interaksi hubungan saling percaya sehingga peserta lansia dapat melanjutkan ke tahap penerimaan informasi.

Hasil penelitian yang dilakukan pada lansia bahwa salam terapeutik sangat efektif sebagai proses interaksi interpersonal antara perawatpasien (Kushariyadi, 2017) menggunakan pendekatan terencana dalam mempelajari pasien berfokus pada kebutuhan spesifik pasien untuk meningkatkan pertukaran informasi efektif yang dipimpin dan direncanakan oleh seorang professional (Videbeck, 2013).

\section{Evaluasi Pertemuan}

Evaluasi pertemuan berisi tentang persiapan peserta yang akan diberikan edukasi yaitu lansia, dan menanyakan kondisi kesehatan peserta. Persiapan peserta lansia meliputi kehadiran lansia sesuai waktu yang dijadualkan dalam kegiatan serta sikap kooperatif lansia yang dibuktikan dengan mengisi absen hadir di berita acara yang diikuti sebanyak 11 lansia yang sudah disediakan oleh petugas kesehatan. Menanyakan kondisi kesehatan peserta lansia yang bertujuan untuk mengetahui tingkat kesiapan keikutsertaan peserta lansia dalam kondisi sehat dan fit sebagai bentuk rasa empati dan kepedulian petugas kesehatan terhadap kondisi peserta lansia pada saat sebelum memulai edukasi.

Hasil penelitian menunjukkan bahwa rasa empati merupakan cara atau kemampuan petugas kesehatan memahami makna, perasaan, mengkomunikasikan pemahaman, mampu menempatkan diri dan melihat hati dari kondisi atau posisi pasien. Empati dapat terjadi saat petugas kesehatan mendengarkan dengan penuh pemahaman dan kepedulian. Petugas kesehatan memperoleh pencitraan perasaan pasien tentang pengalamannya, jika mendengarkan dan merasakan pentingnya situasi pasien (Engvig et al, 2012).

\section{Kontrak (Topik, Waktu, dan Tempat)}

Kontrak (topik, waktu, dan tempat) berisi tentang tema pokok bahasan yang akan disampaikan dalam edukasi yaitu sosialisasi informasi dan komunikasi jaminan kesehatan BPJS dalam meningkatkan pelayanan kesehatan lansia. Kontrak waktu berisi tentang jadwal edukasi yang akan dilaksanakan pada bulan Nopember 2019. Kontrak tempat berisi lokasi edukasi di Karang Werdha lansia 
Kecamatan Sumbersari, Kabupaten Jember. Tahapan ini bertujuan untuk membina hubungan saling percaya, menghargai, menghormati, kejujuran, ketertarikan, dan keterbukaan antara tenaga kesehatan yang memberikan edukasi dengan lansia dan meningkatkan rasa percaya diri lansia terhadap kemampuannya dalam menerima dan kooperatif terhadap informasi dan komunikasi yang disampaikan oleh tenaga kesehatan. Petugas kesehatan juga lebih optimal dan mempunyai kepercayaan diri saat menyampaikan informasi tentang tema di dalam edukasi tersebut.

Petugas kesehatan memperlihatkan tingkah laku percaya penuh, menyampaikan integritas, kehandalan, konsisten, bersikap terbuka, memberi tanggapan jujur dan memperkuat rasa aman. Perilaku petugas kesehatan yang dapat membangun kepercayaan pasien seperti merawat, keterbukaan, objektivitas, menghormati, ketertarikan, pemahaman, konsistensi, memperlakukan pasien sebagai manusia, menunjukkan tanpa memberitahu, mendekati, mendengarkan, menepati janji, kejujuran. Petugas kesehatan dan pasien saling menjaga keterbukaan, mengembangkan kepercayaan, iklim yang mendukung dan mengurangi gangguan sehingga pasien menerima bantuan (informasi) yang ditawarkan (Nasir \& Muhith, 2011).

\section{Tahap 2: Kerja}

Tahap kerja atau tahap implementasi merupakan tahap inti penyampaian informasi dan komunikasi melalui edukasi yang akan mengetengahkan sub-sub tema meliputi: 1) pengertian BPJS; 2) jenis-jenis BPJS; 3) pelayanan-pelayanan dalam BPJS; 4) pembayaran iuran BPJS; 5) prosedur pendaftaran BPJS; 6) manfaat BPJS bagi lansia. Tahap ini bertujuan untuk memberikan informasi secara lengkap dan jelas terhadap lansia sehingga dapat meningkatkan pemahaman lansia terhadap jaminan kesehatan BPJS dalam meningkatkan pelayanan kesehatan.

\section{Pengertian BPJS}

BPJS kesehatan yaitu asuransi jaminan kesehatan yang menjamin segala biaya pengobatan, pelayanan dan penggunaan fasilitas kesehatan untuk seluruh masyarakat Indonesia (BPJS, 2019).

\section{Jenis-jenis BPJS}

Jenis-jenis BPJS kesehatan meliputi: Program Jaminan Hari Tua (JHT), Program Jaminan Kecelakaan Kerja (JKK), Program Jaminan Kematian (JKM), Program Jaminan Pensiun, BPJS Ketenagakerjaan, BPJS-PBI (Penerima Bantuan Iuran), dan BPJS-Non PBI (Bukan Penerima Bantuan Iuran) (BPJS, 2019).

\section{Pelayanan-pelayanan dalam BPJS}

Dasar hukum penyelenggaraan program jaminan social meliputi Undang-Undang Nomor 40 tahun 2004 tentang Sistem Jaminan Sosial Nasional dan Undang-Undang Nomor 24 tahun 2011 mengenai Badan Penyelenggara Jaminan Sosial.

Beberapa kesehatan yang ditanggung oleh BPJS meliputi:

a. Pelayanan kesehatan tingkat satu yaitu pelayanan kesehatan bukan spesialistik meliputi: 1) administrasi pelayanan; 2) pelayanan promotif dan preventif; 3) pemeriksaan, pengobatan dan konsultasi medis; 4) tindakan medis bukan spesialistik (operatif dan non operatif); 5) pelayanan obat dan bahan medis habis pakai; 6) transfusi darah sesuai kebutuhan medis; 7) pemeriksaan penunjang diagnosis laboratorium tingkat satu; 8) rawat inap tingkat satu sesuai indikasi.

b. Pelayanan kesehatan rujukan tingkat lanjutan yaitu pelayanan kesehatan:

1) Rawat jalan: a) administrasi pelayanan; b) pemeriksaan, pengobatan dan konsultasi spesialistik oleh dokter spesialis dan subspesialis; c) tindakan medis spesialistik sesuai indikasi medis; d) pelayanan obat dan bahan medis habis pakai; e) pelayanan alat kesehatan implant; f) pelayanan penunjang diagnostik lanjutan sesuai indikasi medis; g) rehabilitasi medis; h) pelayanan darah; i) pelayanan kedokteran forensic; $j$ ) pelayanan jenazah di fasilitas kesehatan.

2) Rawat inap: a) perawatan inap bukan intensif; b) perawatan inap di ruang intensif; c) pelayanan kesehatan lain ditetapkan oleh Menteri.

Dalam hal peserta jaminan kesehatan menghendaki kelas perawatan yang lebih tinggi, selisih biaya menjadi beban peserta dan/atau asuransi swasta yang diikuti peserta. 
Dalam hal peserta memerlukan pelayanan kesehatan tingkat lanjutan, fasilitas kesehatan tingkat pertama harus merujuk ke fasilitas kesehatan rujukan tingkat lanjutan terdekat sesuai dengan sistem rujukan yang diatur dalam ketentuan peraturan perundangundangan.

Peserta yang memerlukan pelayanan gawat darurat dapat langsung memperoleh pelayanan di setiap fasilitas kesehatan. Peserta yang menerima pelayanan kesehatan di fasilitas yang tidak bekerjasama dengan BPJS Kesehatan, harus segera dirujuk ke fasilitas kesehatan yang bekerjasama dengan BPJS Kesehatan setelah keadaan gawat daruratnya teratasi dan pasien dalam kondisi dapat dipindahkan. Hal ini juga telah diatur dalam Undang-Undang Nomor 40 tahun 2004 Tentang Sistem Jaminan Sosial Nasional dan Undang-Undang Nomor 24 tahun 2011 Tentang Badan Penyelenggara Jaminan Sosial.

Hasil penelitian mengenai Pelayanan Kesehatan yang berada di Ruang Rawat Inap Peserta Pengguna BPJS di RSUD Dr. Soedarso Kalimantan Barat didapatkan rumah sakit sudah memberikan pelayanan dan fasilitas yang cukup baik, namun terdapat beberapa fasilitas yang kurang baik berhubungan dengan fasilitas yang berada di ruang rawat inap sehingga berdampak pasien dan keluarga merasa tidak nyaman dalam beristirahat (Sumpri, 2016).

Hasil penelitian tentang Evaluation of Universal Health Coverage Policy: A Comparison Study Between Indonesia and Thailand didapatkan implementasi Universal Health Coverage di Thailand berhasil dicapai dengan cara mempertahankan standar fasilitas dan kualitas pelayanan kesehatan di rumah sakit. Implementasi Universal Health Coverage di Indonesia belum terpenuhi luaran targetnya, dana pelayanan kesehatan dan kualitas pelayanan Jaminan Kesehatan Nasional masih minim (Mutiarin et al, 2019).

\section{Pembayaran iuran BPJS}

Pembayaran iuran BPJS berdasarkan Peraturan Presiden Nomor 28 Tahun 2016 Tentang Perubahan Ketiga Peraturan Presiden nomor 12 Jaminan Kesehatan. Ketentuan ayat (1) huruf a Pasal 16F berubah menjadi: Pasal 16F:
(1) Iuran Jaminan Kesehatan untuk Peserta Pekerja Bukan Penerima Upah dan Peserta bukan Pekerja:

a. Sejumlah Rp 25.500,00 per orang per bulan untuk pelayanan di ruang perawatan Kelas III.

b. Sejumlah Rp 51.000,00 per orang per bulan untuk pelayanan di ruang perawatan Kelas II.

c. Sejumlah Rp 80,000,00 per orang per bulan untuk pelayanan di ruang perawatan Kelas I.

Berdasarkan Peraturan Presiden Republik Indonesia Nomor 82 Tahun 2018 Tentang Jaminan Kesehatan Pasal 34(1) dan Peraturan Presiden Nomor 75 Tahun 2019 tentang Perubahan Atas Peraturan Presiden Nomor 82 Tahun 2018 Tentang Jaminan Kesehatan.

Pasal 34:

(1) Iuran bagi Peserta PBPU dan Peserta BP yaitu sebesar:

a. sebesar Rp 42.000,00 (empat puluh dua ribu rupiah) per orang per bulan dengan manfaat pelayanan di ruang perawatan Kelas III

b. sebesar Rp 110.000,00 (seratus sepuluh ribu rupiah) per orang per bulan dengan manfaat pelayanan di ruang perawatan Kelas II.

c. sebesar Rp 160,000,00 (seratus enam puluh ribu rupiah) per orang per bulan dengan manfaat pelayanan di ruang perawatan Kelas I.

\section{Prosedur pendaftaran BPJS}

Prosedur pendaftaran BPJS terlihat pada gambar 3.

\section{Manfaat BPJS bagi lansia}

Manfaat BPJS kesehatan bagi lansia antara lain (BPJS, 2019):

a. Menjamin semua biaya pengobatan, pelayanan dan fasilitas kesehatan secara gratis dengan ketentuan.

b. Bisa digunakan di seluruh rumah sakit, puskesmas, klinik, dokter praktik, bidan praktik yang terdaftar kerjasama dengan BPJS kesehatan.

c. Bisa memilih hak kelas 1 atau kelas 2 atau kelas 3 jika dirawat di rumah sakit.

Hasil penelitian di puskesmas di wilayah Kota Yogyakarta bahwa kualitas pelayanan kesehatan lansia menunjukkan peningkatan 
yang berdampak pada peningkatan kesehatan lansia, lansia tetap produktif melakukan aktifitas kegiatan hidup sehari-hari (Khozin \& Mutmainah, 2018).

Hasil penelitian di posyandu lansia yang merupakan pos pelayanan terpadu untuk masyarakat usia lanjut di suatu wilayah tertentu yang sudah disepakati, yang digerakkan oleh masyarakat dimana lansia bisa mendapatkan pelayanan kesehatan. Bertujuan meningkatkan jangkauan pelayanan kesehatan lansia di masyarakat, sehingga terbentuk pelayanan kesehatan yang sesuai dengan kebutuhan lansia, mendekatkan pelayanan dan meningkatkan peran serta masyarakat (Rusmin, Bujawati, \& Baso, 2017).

Hasil penelitian bahwa pemanfaatan 7 fasilitas pelayanan kesehatan oleh lansia menunjukkan ada hubungan antara faktor jarak tempuh, penggunaan asuransi, jenis kelamin, dan status perkawinan. Pemanfaatan 7 fasilitas pelayanan kesehatan oleh lansia menunjukkan banyak lansia yang menggunakan asuransi di rumah sakit pemerintah. Pemanfaatan fasilitas pelayanan kesehatan oleh lansia dipengaruhi oleh multifaktor (predisposing, enabling dan need) terutama jarak tempuh, asuransi, jenis kelamin dan status perkawinan. Pemanfaatan fasilitas kesehatan paling banyak dikunjungi adalah puskesmas, perawat/bidan praktek dan rumah sakit pemerintah (Tamimi, 2016).

Hasil penelitian tentang pemanfaatan pelayanan kesehatan bahwa yang mempengaruhi pemanfaatan pelayanan kesehatan adalah need (kebutuhan) dimana lansia mencari tindakan pengobatan, tindakan itu dirasakan sebagai kebutuhan. Kebutuhan merupakan dasar dan stimulus langsung untuk menggunakan pelayanan kesehatan. Oleh karena itu, baik pengetahuan lansia tinggi maupun rendah, lansia tetap mau untuk memanfaatkan kembali pelayanan puskesmas karena dirasakan sebagai kebutuhan oleh lansia (Setyarini, Arso, \& Suparwati, 2017).

Hasil penelitian tentang pemanfaatan posyandu lansia bahwa hal tersebut dipengaruhi oleh jenis kelamin, status perkawinan, persepsi sehat sakit dan persepsi kualitas pelayanan. Sehingga kader dan petugas kesehatan diharapkan dapat meningkatkan kualitas pelayanan dan penyuluhan posyandu lansia (Purwadi, Hadi, \& Hasan, 2013).

\section{Tahap 3: Resolusi}

Tahap resolusi atau terminasi meliputi: 1) evaluasi berisi tentang evaluasi respons peserta edukasi secara subyektif dan obyektif; 2) tindak lanjut berisi tentang penugasan atau latihan mandiri untuk peserta edukasi tentang tema yang telah diberikan oleh tenaga kesehatan; 3) kontrak yang akan datang berisi tentang topic atau tema baru yang akan disampaikan, waktu atau jadual edukasi, dan tempat edukasi.

Tahap ini bertujuan sebagai evaluasi yang dilakukan pada lansia yang berupa evaluasi proses dan hasil terhadap edukasi yang telah dilakukan untuk mengetahui keberhasilan kegiatan.

\section{Evaluasi berisi tentang evaluasi respons peserta edukasi secara subyektif dan obyektif}

Evaluasi keberhasilan sosialisasi informasi dan komunikasi jaminan kesehatan BPJS dalam meningkatkan pelayanan kesehatan lansia menggunakan deep interview atau wawancara mendalam menggunakan pertanyaan yang bersifat terbuka terhadap peserta lansia mengenai tema yang didapat dari kegiatan edukasi.

Dari ketiga pertanyaan yang ditujukan pada peserta lansia, dapat disimpulkan bahwa sosialisasi informasi dan komunikasi ini sangat bermanfaat untuk pelaksanaan edukasi atau penyuluhan pada lansia. Hal tersebut terlihat dari tema hasil deskripsi dari peserta lansia yaitu:

Tema: Penggunaan media leaflet dan edukasi sebagai komponen sosialisasi informasi dan komunikasi yang dapat mempermudah pemahaman peserta lansia.

"........saya sangat memahami setelah membaca leaflet terutama yang berisi poinpoin singkat dan jelas mengenai apa itu BPJS........."

".........media ini sangat mengena karena dapat memberikan gambaran secara jelas dan gamblang tentang informasi dan komunikasi tentang pelayanan BPJS kesehatan........."

Tema: Informasi dan komunikasi mengenai fasilitas yang ditanggung oleh BPJS sangat 
membantu peserta lansia menuju pusat layanan kesehatan.

“...........kami para lansia tentunya sangat senang dengan adanya program BPJS kesehatan yang secara nyata sangat membantu pelayanan kesehatan terutama di hari tua........"

Tema: Penggunaan bahasa lokal untuk menjelaskan semua informasi dan komunikasi mengenai jaminan kesehatan BPJS dalam meningkatkan pelayanan kesehatan lansia terhadap peserta lansia sangat bermanfaat.

“...........komunikasi secara langsung dengan menggunakan bahasa Jawa timuran sangat membantu kami semakin dalam memahami informasi yang diberikan......."

1. lanjut berisi tentang penugasan atau latihan mandiri untuk peserta edukasi tentang tema yang telah diberikan oleh tenaga kesehatan.

Peserta lansia mendapatkan tugas untuk memberikan atau menularkan ilmu yang didapat saat diskusi kegiatan ini kepada para tetangga di rumah masing-masing. Para peserta lansia mempunyai tanggung jawab secara pribadi untuk memberikan informasi dan komunikasi mengenai pengertian BPJS kesehatan sampai dengan manfaat yang bisa dirasakan terhadap kesehatan yang didapatkan dari pelayanan kesehatan yang disediakan oleh pemerintah secara gratis dan bertanggung jawab.

2. Kontrak yang akan datang berisi tentang topic atau tema baru yang akan disampaikan, waktu atau jadual edukasi, dan tempat edukasi.

Kontrak kegiatan edukasi yang akan diselenggarakan di periode yang akan datang dengan tema yang berbeda. Sehingga diharapkan dapat menjadi kegiatan yang dapat dilaksanakan secara berkelanjutan dengan tema-tema diskusi kesehatan yang menarik dan sesuai dengan situasi dan kondisi lansia saat ini.

\section{KESIMPULAN}

Kegiatan sosialisasi informasi dan komunikasi jaminan kesehatan BPJS dalam meningkatkan pelayanan kesehatan lansia dapat meningkatkan pemahaman pola pikir tentang pola hidup sehat lansia, sehingga lansia tetap produktif dan mendapatkan pelayanan kesehatan yang terpenuhi secara komprehensif dan bertanggung.

Saran terhadap pengabdian yang selanjutnya yaitu mensosialisasikan kebijakankebijakan kesehatan tentang jaminan hukum dan hak-hak pelayanan kesehatan terhadap lansia.

\section{DAFTAR PUSTAKA}

Widiastuti, I. (2018). Pelayanan Badan Penyelenggara Jaminan Sosial (BPJS) Kesehatan di Jawa Barat. Public Inspiration: Jurnal Administrasi Publik. 2018;2(2):91-101.

BPJS. (2019). BPJS Kesehatan: Fasilitas Kesehatan. BPJS Kesehatan. Available from: https://www.bpjskesehatan.go.id/.

Engvig, A., Fjell, A.M., Westlye, L.T., Skaane, N.V., Sundseth, $\varnothing$, \& Walhovd, K.B. (2012). Hippocampal subfield volumes correlate with memory training benefit in subjective memory impairment. Neuroimage. 2012;61(1):188-194.

Infodatin Kemenkes RI. (2016). Situasi Lanjut Usia (Lansia) di Indonesia. On line at http://www depkes go $\mathrm{id} /$ resources/download/pusdatin/infodat in/infodatin\% 20lansia. 2016;202016.

Khozin, M., \& Mutmainah, N.F. (2018). Kualitas Pelayanan Kesehatan Lansia di Kota Yogyakarta (Studi kasus pelayanan kesehatan pada Puskesmas Mantrijeron). Jurnal Manajemen Pelayanan Publik. 2018;1(2):143-155.

Kushariyadi. (2017). Memory Stimulation, Intervention Increase Elderly Cognitive Function. Jurnal Ners. 2017;8(2):317-329.

Mutiarin, D., Tamronglak, A., Suranto, S., Darumurti, A., \& Sakir, S. (2016). Moving Towards Evaluation Sustainable Universal Health Coverage Finance Policy: A Comparison Study Between Indonesia and Thailand. Prosiding ICOGISS 2019. 2019;669-689.

Nasir, A., \& Muhith, A. (2011). Dasar-dasar keperawatan jiwa: pengantar dan teori. Jakarta: Salemba Medika. 
Purwadi, H., Hadi, H., \& Hasan, M.N. (2013). Faktor Yang Mempengaruhi Pemanfaatan Posyandu Lansia di Imogiri Kabupaten Bantul. Jurnal Ners dan Kebidanan Indonesia. 2013;1(3):76-81.

Rosidah, R., \& Apriyani, Y. (2018). Analisis Pelayanan BPJS pada Rumah Sakit Graha Husada Bandar Lampung. Jurnal Perspective Business. 2018;2(1).

Rusmin, M., Bujawati, E., \& Baso, N.H. (2017). Faktor-Faktor yang Berhubungan Dengan Pemanfaatan Posyandu Lansia di Wilayah Kerja Puskesmas Somba Opu Kabupaten Gowa Tahun 2015. Al-sihah: The Public Health Science Journal.2017;9(1).

Setyarini, R., Arso, S.P., \& Suparwati, A. (2017). Faktor-Faktor yang Berhubungan dengan Pemanfaatan Ulang Puskesmas Santun Lansia Karangdoro Kota Semarang Tahun 2016. Jurnal Kesehatan Masyarakat (eJournal). 2017;5(2):16-24.
Sumpri, M. (2016). Pelayanan Kesehatan Ruang Rawat Inap Peserta Pengguna BPJS RSUD Dr. Soedarso Kalimantan Barat. PUBLIKA-Jurnal Ilmu Administrasi Negara. 2016;4(4):1-11.

Tamimi, N. (2016). Pemanfaatan Pelayanan Kesehatan Bagi Kelompok Lanjut Usia (LANSIA). (Analisis Data IFLS4/SAKERTI 2007). UGM Repositotory. 2016.

Widiastuti, I. (2018). Pelayanan Badan Penyelenggara Jaminan Sosial (BPJS) Kesehatan di Jawa Barat. Public Inspiration: Jurnal Administrasi Publik. 2018;2(2):91-101.

Videbeck, S.L. (2013). Psychiatric-mental health nursing. Lippincott Williams \& Wilkins; 2013.

Vinsur, E.Y.Y., \& Sutiyarsih, E. (2019). Analisi Faktor yang Mempengaruhi Lansia datang ke Pelayanan Kesehatan. Jurnal Ners dan Kebidanan (Journal of Ners and Midwifery). 2019;6(2):189-196. 